\title{
Science Proceedings Series
}

(SPS)

www.readersinsight.net/SPS

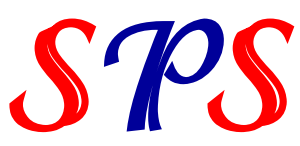

\section{SURVEY ON LOCAL POSITIONING SYSTEM AND IT'S APPLICATIONS}

\section{Hameedah Sahib Hasan}

Ministry of Higher Education and Scientific Research University Iraq.

\section{Mohamed Hussein}

Faculty of Mechanical Engineering

UTM, Johor Bauru Malaysia.

\section{Shaharil Mad Saad*}

Faculty of Mechanical Engineering

UTM, Johor Bauru

Malaysia.

\section{Mohd Azuwan Mat Dzahir}

Faculty of Mechanical Engineering

UTM, Johor Bauru

Malaysia.

*Corrosponding author's Email: shaharil@utm.my

Peer-review under responsibility of $3^{\text {rd }}$ Asia International Multidisciplanry Conference 2019 editorial board 


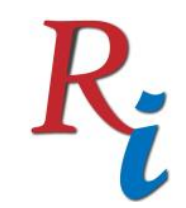

\section{Science Proceedings Series (SPS) \\ www.readersinsight.net/SPS}

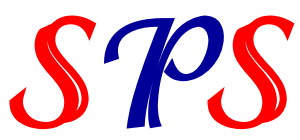

\section{A B S T R A C T}

Global position system (GPS) and Local position system (LPS) have important rols in several applications in real life such as helthcare, monitoring and tracking, etc. GPS has many limitations due to some reason, the signal has lack when used inside bulding this is becouse of lack of line of sight (LoS). Therefore LPS is one of best solution which used to avoide weakness problem and it become very necessary for estimate user's or object position inside buliding with a good accuracy. This paper gives a servay on LPS technologies. Furthermore, the LPS's applications such as trackimg which is involved several types like human tracking, object tracking, animal tracking and AGV tracking which is done by previous researches are presented

Keywords: LPS; GPS; LPS Techniques and Application; Tracking, AGV.

\section{INTRODUCTION}

Positioning system is navigation system which give a position information of the object or people at any location. Position system contained two parts, first, is GPS and another is LPS. GPS gives a position of the object/person on the outside area or earth surface with longitude and latitude coordinates (1). Generally GPS has several limitations firstly, the signal of GPS satellite is slowly because it need to pass through the atmosphere. Secondly, due to the lack of LoS to satellite, GPS signal is blocked through any obstacle. Thus, the GPS is not appropriate for finding the position in indoor (2)(3). On the other hand, LPS is approach used to estimate the location of persons or objects inside a building. There are a several technologies in LPS like infrared (IR), Bluetooth, ultrasound systems, radio frequency identification (RFID, Wi-Fi (4).

\section{TYPICAL OF LOCAL POSITIONING TECHNOLOGIES:}

In order to determine the location of object / people inside bulding there are several LPS technologies can be used. More information of each technology as follows:

1. Infrared Radiation (IR) Technology: This technologe used to track people or object by using both of infrared emitters and receivers. The accuracy of IR is $57 \mathrm{~cm}$ to $2.3 \mathrm{~m} \mathrm{(5)}$.

2. Wi-Fi Technology: It is used widly in LPS for several reason such as it is not require to any LoS also the ability to find the location of person or object is good (4).

3. Ultra-wideband (UWB) Technology: UWB is regarded as wireless technology. It can estamate location of any object by using ultra - short pluse which is depended on radio signals (6).

\section{LPS APPLICATIONS:}

There are several applications can be used to estamate position in LPS such as tracking (4). There are vareios of traching types whish is following:

1. Human Tracking: Here depth camera used to track and detect human's position in LPS application, it is not need to utilze any RGB camera and wearable device(7).

2. Object Tracking: It is used a camera based localization for detecting position change of object without required to use extra references(1). IR system also used to find the location of the object.

3. Animal Tracking: Basically, to determine the motion of animal tracking, the video tracking technology is used. It is implementation for used to find the poition and motion of mice's $\operatorname{limbs}(8)$. 


\section{$R_{i}$}

\section{Science Proceedings Series (SPS) \\ www.readersinsight.net/SPS}

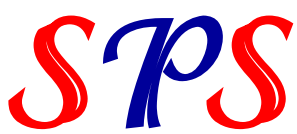

4. AGV Tracking: It uses widely in manufacturing system in different application. Nowadays other application of AGV is extensively developed in different area such warehouse, container terminals and transportation system.

\section{RESULTS}

Table 1. Comparision of LPS

\begin{tabular}{cccc}
\hline Technology & Accuracy $(\mathbf{m})$ & Researcher & Coverage (m) \\
\hline IR & $1-2,0.57-2.3,0.01$ & Chaimaa (2017), Brena (2017), Luca(2014) & Good Indoor,1-5 \\
UWB & $0.2,0.025$ & Khaoula (2016), Luca (2014) & $50-100,15-25$ \\
Wi-Fi & $1-5$ & Chaimaa (2017), Farid (2013), Luca (2014) & Building level, 20-50 \\
\hline
\end{tabular}

Table 2. Comparison between LPS technology and it's techniques

\begin{tabular}{cccc}
\hline Technology & Techniques & $\begin{array}{c}\text { Typical } \\
\text { Environment }\end{array}$ & Researcher \\
\hline IR & $\begin{array}{c}\text { Proximity TOA, Thermal } \\
\text { imaging active beacons }\end{array}$ & Indoor & $\begin{array}{c}\text { Chaimaa(2017), Farid(2013), } \\
\text { khaoula(2016) }\end{array}$ \\
UWB & TOA, TDOA, Simulation TDOA & Indoor & $\begin{array}{c}\text { Khaoula (2016), Luca (2014), } \\
\text { Mohamed R. Mahfouz (2008) }\end{array}$ \\
Wi-Fi & $\begin{array}{c}\text { Proximity TOA, TDOA, RSSI, } \\
\text { Theoretical propagation model. }\end{array}$ & $\begin{array}{c}\text { Building level, } \\
\text { Indoor }\end{array}$ & $\begin{array}{c}\text { Chaimaa (2017),Farid(2013), } \\
\text { khaolua (2016) }\end{array}$ \\
\hline
\end{tabular}

\section{CONCLUSION}

This paper give a servay of LPS includes technologies and it's application. On the other hand, the comparison between LPS technologies is also introdused. Moreover, the LPS's applications such as trackimg which is involved several types like human tracking, object tracking, animal tracking and AGV tracking which is done by previous researches are presented.

\section{ACKNOWLEDGEMENT}

The authors wish to thank to Ministry of Higher Education, Malaysia (MoHE) and Universiti Teknologi Malaysia (UTM) for providing the funding and facilities to conduct this research with Project No. R.J130000.7824.4F839 and Q.J130000.2524.20H25.

\section{REFERENCES}

1. Mainetti L, Patrono L, Sergi I. A survey on indoor positioning systems. 2014 22nd Int Conf Software, Telecommun Comput Networks. 2014;111-20.

2. Medina.C, Segura. J. C. and D la T. "Ultrasound indoor positioning system based on a lowpower wireless sensor network providing sub-centimeter accuracy,." Sensors (Switzerland),. 2013;13, n:3501-3526.

3. Basri C, El Khadimi A. Survey on indoor localization system and recent advances of WIFI fingerprinting technique. Int Conf Multimed Comput Syst -Proceedings. 2017;253-9.

4. Hameedah Sahib Hasan, Mohamed Hussein S. M. S and M. A. MD. An Overview of Local Positioning System : Technologies, Techniques and Applications. Int J Eng Technol. 2018;7:15.

5. Brena RF, García-Vázquez JP, Galván-Tejada CE, Muñoz-Rodriguez D, Vargas-Rosales C, Fangmeyer J. Evolution of Indoor Positioning Technologies: A Survey. J Sensors. 2017;2017.

6. Angrisani L, Arpaia P, Gatti D. Analysis of localization technologies for indoor environment. 2017 IEEE Int Work Meas Networking, M N 2017 - Proc. 2017;0-4.

7. Saputra M. Indoor human tracking application using multiple depth-cameras. Int Conf Adv Comput Sci Inf Syst. 2012;(2):3-8.

8. Q..X, Cong. C. ZH and RH. "A Video Tracking System for Limb Motion Measurement in Small Animals,." Int Conf Optoelectron Image Process (ICOIP), Haiko, 11- 12 Nov. 2010;pp. 181-4. 